\title{
Dinamika Konsep Diri pada Remaja Perempuan Pembaca Teenlit
}

\author{
Novia Dwi Rahmaningsih ${ }^{1}$, Wisjnu Martani ${ }^{2}$ \\ Fakultas Psikologi Universitas Gadjah Mada
}

\begin{abstract}
This study aimed to understand the dynamics of self-concept among teenage girls who read teenlit. The subjects of this study were three high school students who had actively read teenlit for at least two years. In addition, the data were obtained also from five informants who often interacted and could provide an overview about the subjects. This study used a qualitative method with phenomenological approach. Data were collected through indepth interview on subjects and informants, observation during interview and use of teenlit as written document. The findings indicated that characters in teenlit influenced the girls' selfconcept through the mechanism of social comparison and modeling. By observing various characters found in the teenlits they read, they tended to pay attention to a teenlit's characters that are superior to themselves. Therefore, such comparison led them to have negative selfconcept. However, if they had made critical self-appraisal based on a motive of selfimprovement while comparing themselves with the characters, they would have had positive self-concept. It can be concluded that a character that is considered better may become a model for the formation of an ideal self-concept. Through modeling, youth also form an actual self-concept of which is previously less aware.
\end{abstract}

Keywords: modeling, self-concept, social comparison, teenlit

\begin{abstract}
Abstrak. Penelitian ini bertujuan untuk memahami dinamika konsep diri pada remaja perempuan pembaca teenlit. Subjek dari penelitian ini adalah tiga pelajar SMA yang aktif membaca teenlit selama minimal dua tahun. Selain itu, sumber data juga diperoleh dari lima informan tahu yang sering berinteraksi dan dapat memberikan gambaran tentang diri subjek. Penelitian ini menggunakan metode kualitatif dengan pendekatan fenomenologi. Data diperoleh melalui wawancara mendalam pada subjek dan informan tahu, observasi selama wawancara berlangsung, dan penggunaan teenlit sebagai dokumen tertulis. Hasil penelitian ini menunjukkan bahwa tokoh-tokoh dalam teenlit memengaruhi konsep diri pembaca melalui mekanisme perbandingan sosial dan modeling. Melalui pengamatan terhadap berbagai tokoh teenlit, remaja cenderung memperhatikan tokoh teenlit yang lebih unggul. Oleh sebab itu, perbandingan sosial ini dapat memicu konsep diri negatif. Namun, perbandingan sosial yang diikuti dengan penilaian kritis ataupun yang berlandaskan motif perbaikan diri memengaruhi timbulnya konsep diri positif. Gambaran tokoh teenlit yang lebih baik menjadi model bagi pembentukan konsep diri ideal. Melalui modeling remaja juga membentuk konsep diri aktual yang sebelumnya kurang disadari.
\end{abstract}

Kata kunci: konsep diri, modeling, perbandingan sosial, teenlit

Masa remaja merupakan masa krusial bagi perkembangan individu, sebab pada

\footnotetext{
${ }^{1}$ Korespondensi mengenai isi artikel ini dapat dilakukan melalui: noviadwi1@yahoo.co.id

${ }^{2}$ Atau melalui: wisjnu_m@ugm.ac.id
}

masa ini individu mengalami transisi biologis, kognitif, maupun sosial. Akibatnya, individu mulai mencari-cari identitasnya (Santrock, 2012). Erikson (dalam Burns, 1993) menyatakan bahwa konsep diri merupakan suatu penelitian terhadap 
identitas pada masa remaja, khususnya perhatian terhadap cara individu dalam memersepsikan dirinya. Konsep diri dipengaruhi oleh beberapa faktor, salah satunya adalah significant others atau orangorang yang dianggap penting oleh individu (Rice \& Dolgin, 2002). Burns (1993) menyatakan bahwa sebagai akibat dari pesatnya perkembangan media massa dan budaya populer, maka perkembangan konsep diri remaja saat ini semakin kompleks. Pandangan ini diperkuat oleh temuan Giles dan Maltby (2004) yang menyebutkan bahwa tokoh-tokoh dalam media massa berpotensi menjadi salah satu orang yang dianggap penting oleh remaja saat ini.

Baran (2006) menyatakan bahwa buku merupakan jenis media massa yang berfungsi sebagai sumber pengembangan diri dan cenderung mendorong refleksi pribadi yang lebih besar bila dibandingkan dengan jenis media lainnya. Berbagai data menunjukkan bahwa teenlit (teenage literature) merupakan genre buku yang laris di pasaran sejak tahun 2000 (Koran Tempo Ruang Baca, Juni 2005). Wiguna dan Dewi (Koran Tempo Ruang Baca, Desember 2007) menambahkan bahwa belasan judul teenlit berada di angka penjualan 7.000-an hingga 11.000-an dengan dua-tiga kali cetak ulang dalam hitungan waktu empat-enam bulan sejak pertama kali diterbitkan. Tak hanya itu, dalam website resmi Gramedia Pustaka Utama, teenlit terbaru karya Esti Kinasih berjudul 'Jingga dalam Elegi' merupakan buku yang paling banyak dibaca. Selain itu, 'Jingga dalam Elegi' juga masuk ke dalam daftar buku yang ingin dibaca terbanyak. Esti Kinasih sendiri didaulat sebagai pengarang terfavorit. Berbagai data ini mengukuhkan kepopuleran teenlit yang masih bertahan hingga saat ini. Bahkan, di jejaring sosial seperti facebook maupun twitter telah terbentuk kelompokkelompok pecinta teenlit.

Teenlit merupakan cerita fiksi tentang kehidupan sehari-hari remaja yang disoroti dari sudut pandang remaja perempuan yang menjadi tokohnya (Djenar, 2012). Lebih lanjut, Dewi (dalam Setijowati \& Kristanto, 2008) menyatakan bahwa teenlit menggunakan gaya bahasa santai dan ringan yang bertujuan untuk mendekatkan dunia cerita dengan dunia nyata yang sehari-hari dialami remaja. Berdasarkan penggambaran tokoh utamanya, Meloni (2006) membagi teenlit dalam dua kategori. The original humorous lit adalah teenlit yang menghadirkan tokoh utamanya sebagai remaja biasa pada umumnya. Sebaliknya, privileged lit merupakan teenlit yang menampilkan tokoh utama sebagai sosok yang berbeda dari realitas remaja kebanyakan, seperti memiliki penampilan fisik cantik dan menarik, berasal dari kelurga kaya raya, tinggal di kawasan elit, berbusana trendi, serta mengencani lawan jenisnya yang memikat.

Mayoritas pembaca teenlit adalah remaja perempuan, sedangkan hanya segelintir remaja laki-laki yang membaca teenlit. Oleh sebab itu, penelitian ini hanya akan menggunakan remaja perempuan sebagai subjeknya. Melalui aktivitas membaca teenlit, teenlit dapat menjadi salah satu sumber pembentukan konsep diri remaja. Seperti yang dinyatakan oleh Hill (dalam Steinberg, 2011), penggunaan waktu luang merupakan salah satu konteks yang berkontribusi terhadap perkembangan psikosial remaja, salah satunya adalah konsep diri.

Berzonsky (1981) mendefinisikan konsep diri sebagai sebuah personal theory yang mencakup seluruh konsep, asumsi, dan prinsip yang dipercayai oleh individu tentang dirinya sepanjang kehidupan. Konsep diri terdiri dari pengetahuan 
individu tentang diri sendiri di masa sekarang, pengharapan individu tentang diri sendiri di masa depan, serta penilaian individu terhadap diri sendiri yang menentukan tingkat harga diri (Calhoun \& Acocella, 1990). Sementara itu, Berzonsky (1981) menyebutkan bahwa konsep diri mencakup pandangan diri terhadap empat dimensi, yaitu: (1) Diri fisik (physical self), meliputi seluruh kepemilikan individu yang terwujud dalam benda-benda nyata seperti tubuh, pakaian, benda material, dan sebagainya. (2) Diri sosial (social self), meliputi peran-peran sosial yang dimainkan oleh individu dan penilaian individu terhadap peran tersebut. (3) Diri moral (moral self), meliputi semua nilai dan prinsip yang dipegang individu dalam kehidupan, dan (4) Diri psikis (psychological self), meliputi pemikiran, perasaan, dan sikap individu terhadap diri sendiri (proses ego).

Berdasarkan wawancara awal pada tiga pembaca teenlit diketahui bahwa remaja melakukan modeling terhadap sifatsifat positif tokoh teenlit dan menjadikannya sebagai konsep diri idealnya. Melalui teenlit, remaja mencermati tokoh-tokoh dalam teenlit, kemudian menjadikan tokoh tertentu sebagai panutannya dan ingin menjadi individu yang menyerupai tokoh tersebut. Subjek menyatakan bahwa tokoh-tokoh dalam teenlit merupakan sumber inspirasi dan sumber pembelajaran. Oleh sebab itu, sebagai salah satu sumber alternatif pengembangan konsep diri pembaca, teenlit diharapkan mampu membantu remaja dalam mengembangkan konsep dirinya secara positif. Menurut Ybrandt (2008), konsep diri positif merupakan faktor protektif bagi individu dari perilaku bermasalah. Sementara itu, konsep diri negatif merupakan prediktor terhadap masalah internal seperti depresi, kecemasan, dan penarikan diri. Lebih lanjut, masalah internal ini memprediksi masalah eksternal yang berhubungan langsung dengan perilaku-perilaku berbahaya dan mengganggu orang lain seperti agresi dan kenakalan remaja.

Bandura (1986) menyatakan bahwa modeling merupakan proses pembelajaran yang diperoleh individu dengan mengamati pola pemikiran atau perilaku orang lain dan konsekuensi yang mengikuti setelahnya. Modeling diawali dengan pengamatan dan persepsi yang dilakukan individu terhadap perilaku model yang dianggap menarik (attentional process). Kemudian, individu mengingat perilaku yang telah diamati tersebut dalam bentuk simbolis (retention process) dan memunculkan perilaku berdasarkan pola perilaku yang telah dipelajari dari pengamatannya (production process). Selanjutnya, individu memilih untuk menggunakan atau menyia-nyiakan pengetahuan yang diperoleh dari pengamatan (motivational process). Dalam hal ini, individu akan semakin bertindak sesuai dengan perilaku model apabila hal tersebut memberikan akibat yang menguntungkan. Menurut Grossberg (2006), teori modeling ini sangat kuat dalam menjelaskan proses belajar individu yang didapat dari media massa dan telah digunakan secara luas untuk memahami pengaruh media massa.

Sayangnya, berbagai penelitian analisis konten menunjukkan bahwa teenlit tidak sepenuhnya menyediakan informasiinformasi positif bagi perkembangan konsep diri pembacanya. Salah satunya adalah temuan penelitian oleh Kameshwari (2008) yang menyebutkan bahwa teenlit mencerminkan kehidupan remaja saat ini yang berkaitan erat dengan hedonisme, konsumerisme, fashionable, dan pergaulan. Sementara itu, sikap hidup yang tercermin dalam teenlit meliputi sikap menutup diri (introvert), cuek, keras 
kepala, angkuh, mudah putus asa, mudah kecewa, serta kurang bertanggungjawab. Qadriani (2012) juga menemukan bahwa teenlit menonjol dalam menampilkan obsesi tokoh-tokohnya untuk meraih popularitas di antara teman sebayanya.

Selain itu, Setijowati dan Kristanto (2008) menyebutkan bahwa perempuan dalam teenlit disebut cantik bila memiliki tubuh tinggi dan langsing, kulit putih, rambut hitam yang panjang dan tebal, berpenampilan seksi dan anggun. Konsep cantik yang sangat sempurna ini dapat menimbulkan konsep diri negatif bila remaja menjadikan hal ini sebagai atribut perbandingan sosial. Sebab, perbandingan fisik dengan dengan konstruksi ideal yang dibangun oleh industri hiburan merupakan salah satu hal yang berpengaruh terhadap konsep diri remaja (Burns, 1993). Khirade (2012) menyatakan bahwa perbandingan sosial merupakan salah satu hal utama yang memengaruhi pembentukan konsep diri remaja. Perbandingan sosial merupakan proses yang dilakukan individu untuk menemukan kesamaan dan perbedaan diri dengan orang lain. Wood (dalam Kranger, Ingledew, \& Iphofen, 2008) menyatakan bahwa perbandingan sosial dapat dilakukan untuk mengevaluasi kedudukan individu (selfevaluation), mempelajari karakteristik tertentu dari orang lain untuk memperbaiki diri (self-improvement), serta menangkis ancaman dan mempertahankan pandangan positif terhadap diri (self-enhancement).

Di sisi lain, Milkie (1999) mengkritisi penelitian tentang efek media massa dengan menggunakan metode kuantitatif sebab penelitian ini tidak dapat melihat peran interpretasi pengguna dalam memediasi efek media massa. Padahal, setiap pengguna media pasti memiliki interpretasi yang berbeda terhadap pesan-pesan media. Terlebih, aktivitas membaca yang dilakukan oleh pengguna teenlit memungkinkan individu untuk menciptakan interpretasi yang berbeda dengan pembaca lainnya sebab membaca merupakan proses individual (Maarof \& Yaacob, 2011) yang melibatkan berbagai aktivitas kognitif yang kompleks (Matlin, 2009). Berdasarkan uraian di atas, maka penelitian ini bermaksud menjawab pertanyaan bagaimana remaja perempuan menginterpretasi pesan-pesan dalam teenlit yang berperan dalam pengembangan konsep dirinya?

\section{Metode}

Fokus dari penelitian ini adalah dinamika konsep diri pada remaja perempuan pembaca teenlit. Sementara itu, tujuan penelitian ini adalah untuk memahami kompleksitas fenomena yang disadari individu. Oleh sebab itu, penelitian ini menggunakan metode kualitatif dengan pendekatan fenomenologi.

Penelitian ini menggunakan tiga sumber data. Pertama, subjek penelitian dengan kriteria remaja perempuan, mampu membedakan teenlit dengan genre lainnya, dan pembaca aktif teenlit minimal selama dua tahun. Kedua, informan tahu, yaitu orang-orang terdekat berasal dari keluarga atau teman yang sering berinteraksi dengan subjek dan dapat memberikan gambaran tentang diri subjek. Penelitian ini menggunakan tiga subjek dan lima informan. Pada subjek ke-3 tidak menggunakan informan yang berasal dari anggota keluarga, sebab subjek ke-3 tidak tinggal dengan keluarga. Ketiga, dokumen tertulis berupa teenlit-teenlit yang digunakan subjek sebagai sumber pengembangan konsep dirinya. Informan tahu dan dokumen berguna untuk memperkaya data dan melakukan check and recheck informasi.

Data-data diperoleh dari ketiga sumber data ini dengan menggunakan tiga 
teknik pengumpulan data, yaitu wawancara mendalam, observasi, dan penggunaan dokumen tertulis. Wawancara mendalam dilakukan pada subjek dan informan dengan menggunakan pedoman umum yang telah disusun sebelumnya. Pedoman umum berguna sebagai pengingat dan pengecek bagi peneliti untuk memastikan bahwa aspek-aspek yang penting dan relevan dalam penelitian telah ditanyakan pada subjek (Poerwandari, 2007). Selama wawancara berlangsung, juga dilakukan observasi terhadap perilaku subjek untuk memperoleh data pendukung. Sementara itu, penggunaan dokumen tertulis dilakukan dengan membaca teenlit-teenlit yang disebutkan subjek dalam wawancara sebagai sumber pengembangan konsep dirinya.

Berbagai data yang telah terkumpul kemudian dianalisis melalui beberapa tahapan. Pada mulanya, data-data diorganisasikan dan diberi kode secara sistematis. Setelah data dipahami, peneliti melakukan analisis awal dengan cara memadatkan data untuk menemukan kata kunci dan koding. Selanjutnya, peneliti mengelompokkan kata-kata kunci serupa ke dalam tema-tema serta mencoba menemukan pola dan hubungan dari tema-tema tersebut. Terakhir, temuan penelitian ditinjau menggunakan teoriteori psikologi.

Penelitian ini menggunakan berbagai sumber data (triangulasi data) dan teknik pengumpulan data (triangulasi metode) sebagai salah satu upaya untuk menguji keabsahan data, yaitu uji kredibilitas. Selain itu, peneliti juga melakukan pengecekan anggota terlibat sebagai teknik pemeriksaan kredibilitas. Dalam hal ini, peneliti meminta subjek untuk memeriksa transkrip wawancara dan hasil analisis sebagai upaya memberikan kesempatan bagi subjek untuk mengoreksi ataupun menentang kesalahan data ataupun penafsiran. Sementara itu, uji dependabilitas diupayakan dengan memastikan koherensi dan keterbukaan metode, serta melakukan diskursus dengan cara mendiskusikan temuan dan analisis pada orang lain.

\section{H a s i 1}

Pada dasarnya setiap subjek telah membentuk berbagai pandangan terhadap dirinya sendiri atau yang biasa disebut dengan konsep diri. Konsep diri ini berbeda antara subjek satu sama lain sebab tiap subjek memiliki latar belakang dan pengalaman yang berbeda pula. Pandangan diri ini mencakup penilaian individu terhadap kelebihan dan kekurangan yang dimiliki di berbagai aspek diri. Konsep diri ini masih terus berubah maupun berkembang sebagai akibat dari pengaruh beberapa faktor, salah satunya adalah tokoh-tokoh di media teenlit.

Subjek memaknai teenlit sebagai cerita fiksi yang ditujukan untuk remaja. Cerita teenlit yang mirip dengan keseharian remaja menjadi daya tarik tersendiri bagi subjek, sebab hal ini membuat teenlit mudah dipahami. Selama bertahun-tahun menekuni teenlit, subjek menemukan banyak tokoh dalam berbagai judul teenlit. Kemudian, setiap subjek memersepsi dan menilai gambaran tokoh-tokoh teenlit ini secara beragam, baik sisi positif atau negatif. Namun, hanya sisi positif tokoh teenlit yang berperan terhadap perkembangan konsep diri subjek.

Pada aspek diri fisik, tokoh teenlit yang memiliki penampilan sempurna dan materi berlimpah menjadi target perbandingan sosial. Subjek memersepsi gambaran tentang kesempurnaan penampilan fisik antar tokoh-tokoh teenlit tersebut secara homogeny, yang dicirikan dengan wajah cantik, tubuh langsing dan tinggi, 
serta kulit putih. Persepsi ini serupa dengan hasil analisis konten oleh Setijowati dan Kristianto (2008) yang menemukan bahwa kecantikan yang ditampilkan melalui tokoh-tokoh teenlit digambarkan dari tubuh yang tinggi dan langsing, kulit putih, rambut hitam, panjang, dan tebal, berpenampilan seksi serta anggun. Perbandingan sosial dengan tokoh yang sempurna dalam aspek fisik ini menempatkan tokoh teenlit dalam posisi yang lebih unggul dari subjek. Ketidakpuasan terhadap aspek fisik rentan timbul pada subjek yang belum menunjukkan penerimaan diri. Tokoh teenlit yang digambarkan sempurna dalam aspek fisik membuat subjek menilai dirinya kurang beruntung dan semakin tidak puas dengan dirinya sendiri. Sementara itu, subjek yang pada mulanya memiliki pandangan diri positif terhadap aspek fisiknya tidak terpengaruh dengan gambaran tokoh ini. Perbandingan dengan tokoh yang lebih unggul dalam aspek fisik ini justru menjadi konsep diri ideal subjek dan terwujud dalam usahausaha perbaikan diri.

Lain halnya, gambaran tokoh teenlit yang berkaitan dengan kualitas-kualitas yang lebih abstrak menghasilkan persepsi yang berbeda antara subjek satu dan lainnya. Akan tetapi, ditemukan sebuah pola serupa yaitu hal yang dipersepsi sebagai gambaran tokoh teenlit cenderung tidak jauh berbeda dengan kualitas abstrak yang dipersepsi subjek sebagai konsep dirinya. Baron dan Byrne (1998) menyebut fenomena ini sebagai selfreference effect, yaitu kecenderungan individu untuk lebih mampu memroses informasi yang relevan dengan diri dibanding informasi-informasi lainnya. Gambaran tokoh teenlit yang bersifat abstrak ini memengaruhi konsep diri individu dalam aspek sosial, moral, dan psikologis. Secara lebih spesifik, teenlit hanya memengaruhi konsep diri sosial dalam hal pandangan diri terhadap peranan individu di lingkungan pergaulan dan pertemanan.

Pada mulanya, subjek mengamati tokoh-tokoh teenlit dalam kehidupannya di kisah teenlit. Selain pengamatan terhadap tokoh teenlit secara menyeluruh, subjek juga mengamati tokoh teenlit tertentu yang menarik perhatiannya. Melalui pengamatan ini, subjek memperoleh suatu informasi yang berisi kesimpulan subjek tentang gambaran tokoh teenlit. Kemudian, subjek menyimpan informasi ini dalam ingatannya. Gambaran tokoh teenlit ini menjadi model bagi subjek dalam memandang dirinya sendiri, terutama konsep diri ideal. Melalui konsep diri ideal ini, subjek berupaya menyerupai tokoh teenlit tersebut bahkan dalam konteks yang lebih luas. Namun, informasi berdasarkan pengamatan ini tidak selalu digunakan oleh subjek sebagai acuan konsep dirinya. Subjek yang merasakan dampak negatif setelah berusaha menyerupai tokoh teenlit kemudian berhenti melakukan modeling dan menerima dirinya sendiri. Mekanisme modeling ini dapat dicermati dalam Gambar 1.

Berbagai persepsi terhadap tokoh teenlit yang diperoleh dari pengamatan tersebut kemudian menjadi atribut perbandingan sosial dan model pembelajaran yang memengaruhi konsep diri subjek pada aspek sosial dan psikologis. Proses ini berlangsung dalam dua jalan yang berbeda. Pertama, subjek membandingkan konsep diri yang telah dimilikinya dengan gambaran tokoh teenlit. Selanjutnya, gambaran tokoh teenlit ini menjadi konsep diri ideal yang mendorong subjek untuk berusaha memperbaiki dirinya mendekati gambaran tokoh teenlit. Kedua, melalui pengamatan terhadap gambaran tokoh teenlit, subjek memperoleh informasi baru untuk menilai aspek-aspek diri yang pada 


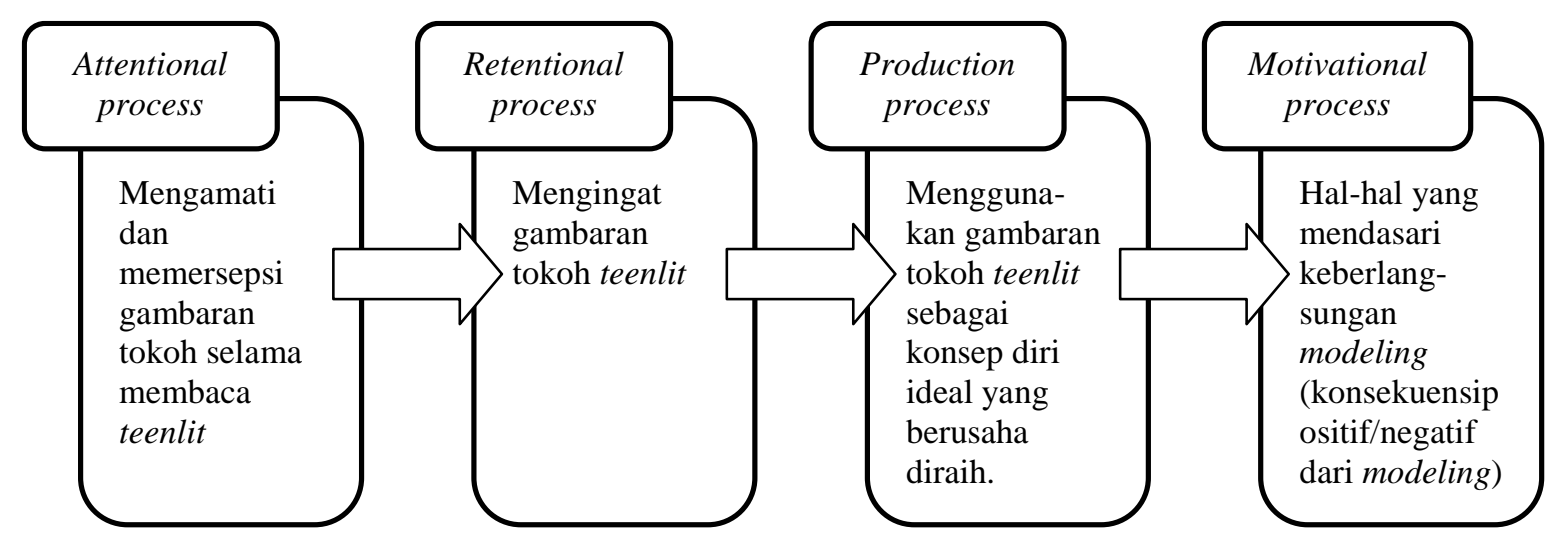

Gambar 1. Mekanisme Modeling Pembaca Teenlit

mulanya kurang disadari. Gambaran tokoh teenlit memunculkan perbandingan sosial yang membuat subjek menemukan konsep diri aktual sekaligus konsep diri idealnya. Perbedaan kualitas diri antara subjek dan tokoh teenlit memacu subjek untuk menyerupai tokoh teenlit.

Dibandingkan dengan dirinya, subjek menilai bahwa tokoh teenlit memiliki kualitas diri yang lebih baik dari dirinya. Perbandingan ini memunculkan keinginan subjek untuk menyerupai tokoh-tokoh teenlit tersebut. Selain itu, subjek juga melakukan perbandingan dengan tokoh teenlit dengan kualitas serupa yang pada akhirnya dapat berubah menjadi diri yang lebih baik. Keberhasilan tokoh teenlit dalam mencapai diri yang diinginkan memberikan keyakinan dan dorongan bagi subjek untuk memperbaiki dirinya seperti tokoh-tokoh teenlit tersebut. Dengan kata lain, tokoh teenlit menjadi sumber bagi pembentukan konsep diri ideal subjek.

Penilaian terhadap perbandingan sosial antara diri subjek dan tokoh teenlit berlangsung dalam proses yang berbeda sehingga memberikan dampak berbeda pula pada konsep diri subjek. Perbandingan sosial antara diri subjek dengan tokoh teenlit yang lebih baik (upward comparison) berpotensi pada timbulnya ketidakpuasan terhadap diri yang berujung pada afek negatif dan konsep diri negatif. Namun, dampak negatif ini tidak timbul bila subjek mampu memberikan penilaian kritis terhadap gambaran tokoh teenlit tersebut, misal dengan menilai gambaran tokoh teenlit sebagai gambaran yang tidak realistis. Pandangan terhadap diri yang positif juga dipertahankan dengan menjadikan berbagai kualitas unggul tokoh teenlit yang dijadikan sebagai atribut perbandingan sosial sebagai konsep diri ideal subjek daripada sebagai bahan evaluasi diri semata.

Sementara itu, pengaruh tokoh teenlit terhadap konsep diri moral subjek berlangsung melalui proses yang berbeda dari konsep diri sosial dan psikologis. Subjek mengamati berbagai prinsip yang dipegang oleh tokoh-tokoh teenlit dan menunjukkan ketertarikan pada prinsip tertentu saja. Selanjutnya, prinsip ini menjadi konsep diri moral subjek yang berusaha dipegang teguh beriringan dengan konsep diri moral yang telah dimiliki subjek sebelumnya.

Gambar 2 adalah bagan untuk mempermudah penjelasan tentang dinamika konsep diri remaja yang dipengaruhi oleh gambaran-gambaran tokoh teenlit.

Selain itu, besarnya pengaruh teenlit terhadap konsep diri subjek berbeda satu 


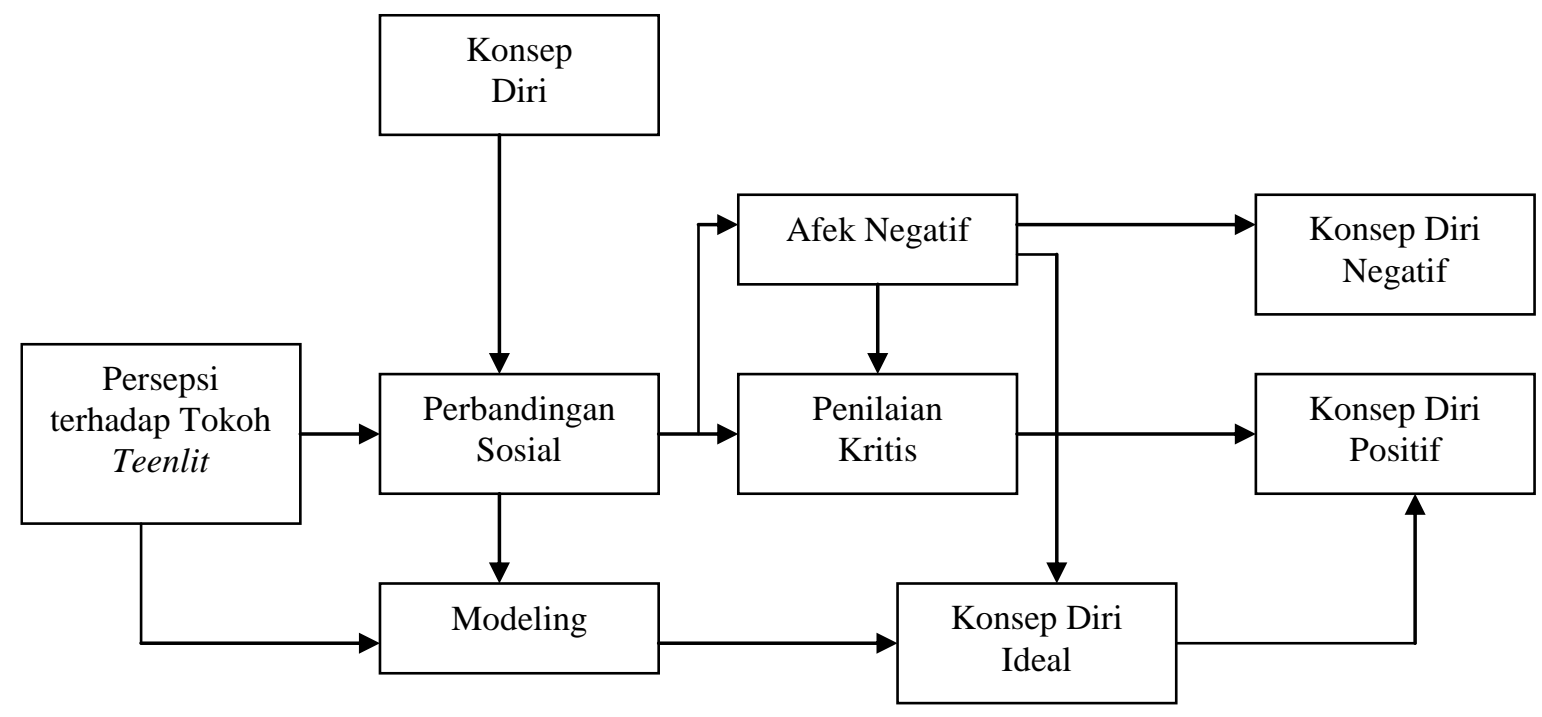

Gambar 2. Dinamika Konsep Diri Pembaca Teenlit

sama lain. Hal ini berkaitan dengan perbedaan pengalaman membaca teenlit antara subjek satu dan lainnya. Misalnya, intensitas, durasi, dan kualitas aktivitas membaca maupun kebiasaan membaca ulang teenlit yang memuat tokoh favoritnya.

\section{Diskusi}

Temuan penelitian ini menunjukkan bahwa pengamatan terhadap tokoh-tokoh menghasilkan berbagai gambaran yang berperan terhadap dinamika konsep diri remaja pembaca teenlit melalui mekanisme perbandingan sosial dan modeling. Tokoh teenlit yang lebih baik mendapat perhatian lebih dari pembaca sebagai target perbandingan sosial (upward comparison) dan model pembelajaran.

Dalam aspek fisik, remaja lebih memperhatikan tokoh teenlit yang memiliki penampilan fisik sempurna dan kekayaan berlimpah. Meloni (2006) menyebut teenlit dengan gambaran tokoh seperti ini sebagai privileged lit sebab memotret kehidupan remaja yang berbeda dengan realitas remaja kebanyakan. Perbandingan sosial dengan tokoh teenlit yang sempurna dalam aspek fisik berdampak pada konsep diri negatif pada remaja yang belum menunjukkan penerimaan terhadap diri fisiknya. Sebaliknya, perbandingan ini tidak menimbulkan penilaian negatif pada remaja yang telah menunjukkan penerimaan terhadap diri fisiknya. Hal senada diungkapkan oleh Bessenoff (2006) yang menemukan bahwa individu dengan tingkat self-discrepancy yang tinggi lebih memperoleh pengaruh negatif dari proses perbandingan sosial terhadap gambaran fisik ideal di media daripada individu dengan tingkat self-discrepancy yang rendah. Pada subjek yang telah memiliki konsep diri fisik positif, perbandingan dengan tokoh yang lebih unggul dalam aspek fisik ini justru menjadi konsep diri ideal subjek dan terwujud dalam usahausaha perbaikan diri. Halliwel dan Ditmar (2005) menemukan bahwa perbandingan sosial terhadap citra fisik ideal dalam media massa yang dimaksudkan untuk mengevaluasi diri (self-evaluation) memberikan dampak negatif pada citra tubuh perempuan, sedangkan perbandingan sosial yang dimaksudkan sebagai perbaikan diri (self-improvement) tidak memberikan pengaruh signifikan terhadap citra tubuh. Dengan kata lain, perbandingan 
sosial yang ditujukan untuk memperbaiki diri dapat mengurangi pengaruh negatif paparan diri fisik ideal dari media terhadap konsep diri fisik individu.

Perbandingan sosial dapat menimbulkan afek dan konsep diri negatif pada remaja pembaca teenlit. Namun, perbandingan sosial yang diiringi dengan penilaian kritis terhadap berbagai gambaran tokoh teenlit membantu remaja dalam mempertahankan konsep diri positif. Kemampuan mengevaluasi dan menganalisis pesan media merupakan bagian dari literasi media (Thoman \& Jolls, 2003) yang berfungsi sebagai mediator dalam pengaruh media terhadap aspek-aspek konsep diri remaja yang masih berkembang. Dalam hal ini, literasi media mengurangi dampak negatif paparan media pada remaja (McLean, Paxtor, \& Wertheim, 2013). Selain itu, konsep diri positif juga diperoleh bila motif perbaikan-diri (selfimprovement) menjadi landasan remaja dalam melakukan perbandingan sosial sehingga tokoh teenlit tersebut menjadi model bagi perkembangan konsep diri ideal remaja. Kesenjangan antara diri real dan diri ideal memang dapat berakibat pada timbulnya afek negatif, tapi di sisi lain juga dapat mendorong remaja untuk mengaktualisasikan diri idealnya (Argyle, 1994).

Gambaran tokoh teenlit menjadi sumber konsep diri ideal yang mendorong pembaca untuk merubah diri aktualnya menuju yang diidealkan. Selain itu, gambaran tokoh teenlit memberikan pemahaman yang lebih luas pada aspek-aspek konsep diri yang sebelumnya kurang disadari. Menurut Bandura (1986), modeling mempengaruhi individu melalui berbagai cara. Dua di antaranya adalah sebagai sumber informasi baru tentang keterampilan koginitif ataupun sebagai dorongan sosial melalui penguatan stimulus terhadap perilaku yang sebelumnya telah dipelajari.

\section{Kesimpulan}

Berdasarkan hasil penelitian dapat disimpulkan bahwa pengamatan terhadap tokoh-tokoh teenlit dapat memengaruhi konsep diri pembaca, baik positif ataupun negatif. Perbandingan sosial yang dilakukan pembaca dengan tokoh teenlit yang lebih unggul dapat menimbulkan konsep diri negatif. Namun, perbandingan sosial yang diikuti oleh penilaian kritis ataupun berlandaskan motif perbaikan diri dapat membantu remaja mempertahankan konsep diri positif. Selain itu, gambaran tokoh teenlit yang lebih baik menjadi model bagi pembentukan konsep diri ideal yang ingin diraih di masa depan. Melalui modeling, remaja juga membentuk konsep diri aktual yang sebelumnya kurang disadari. Oleh sebab itu, terdapat berbagai hal yang dapat dilakukan remaja pembaca teenlit untuk menjaga atau meningkatkan konsep diri positif. Diantaranya adalah meningkatkan penilaian kritis terhadap gambaran tokoh-tokoh teenlit melalui literasi media, meningkatkan pemahaman dan penerimaan terhadap berbagai aspek diri, maupun menjadikan kualitas unggul tokoh teenlit sebagai model pembelajaran daripada sekedar evaluasi diri.

\section{Kepustakaan}

Argyle, M. (1994). The Psychology of Interpersonal Behaviour. London: Penguin Books.

Bandura, A. (1986). Social Foundations of Thought and Action: A Social Cognitive Theory., New Jersey: Prentice-Hall.

Baran, S. L. (2006). Introduction to Mass Communication Media Literacy and Culture. New York: McGraw-Hill. 
Berzonsky, M. D. (1981). Adolescent Development. New York: Macmillan Publishing.

Bessenoff, G. R. (2006). Can the media affect us? Social comparison, selfdiscrepancy, and the thin ideal. Psychology of Women Quarterly, 30, 239-251.

Burns, R. B. (1993). Konsep Diri: Teori, Pengukuran, Perkembangan, dan Perilaku (Terjemahan Eddy). Jakarta: Arcan.

Calhoun, J. F., \& Acocella, J. R. (1990). Psychology of Adjustment and Human Relationship. New York: McGraw-Hill.

Djenar, D. N. (2012). Almost unbridled: Indonesian youth language and its critics. South East Asia Research, 20(1), 35-51. doi:10.5367/sear.2012.0086.

Giles, D. C., \& Maltby, J. (2004). The role of media figures in adolescent development: relations between autonomy, attachment, and interest in celebrities. Personality and Individual Differences, 36, 813-822. doi:10.1016/S01918869(03)00154-5.

Halliwel, E., \& Ditmar, H. (2005). The role of self-improvement and self-evaluation motives in social comparisons with idealised female bodies in the media. Body Image, 2, 249-261. doi:10.1016/j.bodyim.2005.05.001.

Kameswhari, F. A. (2008). Refleksi gaya hidup dan sikap hidup remaja dalam tiga novel remaja Seperti Bintang (Regina Feby, 2005), Impian Moira (Dewie Sekar, 2005), dan Cowok Nyebelin Banget! (Tryanee, 2006). (Tesis tidak dipublikasikan). Fakultas Ilmu Budaya Universitas Dipenegoro. Diunduh dari: http://eprints.undip. ac.id/5884/

Khirade, S. K. (2012). A study of the self concept of the adolescents. Indian Streams Research Journal, 2, 1-6.
Krayer, A., Ingledew, D. K., \& Iphofen, R. (2008). Social comparison and body image in adolescence: a grounded theory approach. Health Education Research, 23(5). 892-903.

Maarof, N., \& Yaacob, R. (2011). Meaningmaking in first and second language: reading strategies of Malaysian students. Procedia Social and Behavioral Sciences, 12, 211-223.

Matlin, M. W. (2009). Cognitive Psychology. New Jersey: John Willey \& Sons.

McLean, S. A., Paxtor, S. J., \& Wertheim, E. H. (2013). Mediators of the relationship between media literacy and body dissatisfaction in early adolescent girls. Body Image, 10, 282-289. http://dx.doi.org/10.1016/j.bodyim.201 3.01.009.

Meloni, C. (2006). Teen chick lit. Library Media Connection, 25(2), 16-19.

Milkie, M. A. (1999). Social comparisons, reflected appraisals, and mass media: the impact of pervasive beauty images of black and white girls' self concept. Social Psychology Quarterly, 62(2), 190210.

Poerwandari, E. K. (2007). Pendekatan Kualitatif Untuk Penelitian Perilaku Manusia. Depok: LPSP3.

Qadriani, N. (2012). Remaja dalam novel populer: kajian semiotika terhadap novel teenlit Indonesia. (Tesis tidak dipublikasikan). Yogyakarta: Universtitas Gadjah Mada.

Rice, F. M., \& Dolgin, K. G. (2002). The Adolescent: Developmental, Relationship, and Culture. Boston: Allyn \& Bacon.

Santrock, J. W. (2012). A Topical Approach to Life Span Development. New York: McGraw-Hill. 
Setijowati, L., \& Khristianto. (2008). Cantik ala remaja dalam novel-novel teenlite. Leksika, 2(1), 50-62.

Sukses setelah mengetuk pintu ke pintu. (2005, Juni). Koran Tempo Ruang Baca. Diunduh dari: http://www.ruangbaca. com/ruangbaca/16/percakapan.htm tanggal 10 Mei 2013.

Thoman, E., \& Jolls, T. (2003). Literacy for the 21st Century: An Overview $\mathcal{E}$ Orientation Guide to Media Literacy
Education. Diunduh dari: http://www. medialit.org/cml-medialit-kit.

Wiguna, O., \& Dewi, A. (2007, Desember). Melawan kutukan tiga ribu eksemplar. Koran Tempo Ruang Baca. Diunduh dari: http://www.ruangbaca.com/ ruangbaca/?doky $=\mathrm{MjAwNw}==\&$ dokm $=\mathrm{MTI}=\&$ dokd $=\mathrm{MzE}=\& \operatorname{dig}=\mathrm{YXJja}$ $\mathrm{Gl} 2 \mathrm{ZXM}=\&$ on $=\mathrm{Q} 1 \mathrm{JT} \& u n i q=\mathrm{NjAz}$ tanggal 25 April 2013. 